\title{
Relationship of River to Salinity Well Water \\ in Bintaran Village, Sub-District Air Salek
}

\author{
Rahayu Rohmana Vidiati Ningrum ${ }^{1}$, Budi Utomo ${ }^{2 *}$ \\ Geography Education, University of PGRI Palembang ${ }^{12}$ \\ 2*budi.banilasmin@gmail.com
}

\begin{abstract}
This study aims to determine the relationship of rivers to salinity of well water in Bintaran Village, Air Salek Sub-district. The research method used is quantitative descriptive. The study population was all wells in Bintaran Village, Air Salek Sub-district, with a sample of 16 samples taken from 8 wells in Bintaran Village, Air Salek Sub-district, in the morning >07.00 Am, and at noon <12.00 Pm. Data collection techniques using observation, laboratory tests, and documentation. Data analysis techniques using produck moment correlation techniques. The results showed that the relationship of the river to the salinity of well water had a significant relationship, namely the morning salt content of the value 0.794 , and the day salt content of the correlation value was 0.807, the closer the well to the river the lower the salt content.
\end{abstract}

Keywords: River, Salinity, and Well Water

\section{Introduction}

Bintaran Village is one of the villages from Air Salek Sub-district in Banyuasin District. Where previously the Air Salek Sub-district was a division of Makarti Jaya Subdistrict and Muara Padang Sub-district. Most of the population has agricultural livelihoods and is a transmigration area from most of the of Java. Where the village of Bintaran is a tidal area of river water, so that it can affect the content of well water, which is like well water that has a briny, and rusty taste.

The color of the well water is different including yellow, muddy, and white (clear), based on the content elements contained in the well water. According to Zhao (2015) explains "soil texture, organic matter content, and bulk density simultaneously can affect retention of ground water or well water". Factors that contribute to turbidity of water include soil erosion, increased input of nutrients that stimulate the growth of algae, waste disposal, and are abundant that fill the base that stirs up sediment. (Schlesinger, 1991; Kumar, et al., 2017: 3) 
Well water as a domestic need, namely water needs as a necessity for domestic life, including for cooking, washing clothes, bathing, washing dishes, and other household needs. In addition, the benefits of well water can also be irrigated on agricultural, during the dry season when rainfall is very low, and as a provider of clean water, if the well water is not muddy (clear), tasteless and no color.

Water quality states the level of suitability of water for certain uses in fulfill the needs of human life, starting from water to fulfill immediate needs, namely drinking water, bathing and washing, irrigation or agricultural water, ranch, fisheries, recreation and transportation. Water quality includes three characteristics, that is physics, chemistry and biology.

Wells in Bintaran Village, Air Salek Sub-district have low water quality. Based on preliminary observations, about the salinity of well water to the distance of the river to the well found in the village, it is known that well water has a salty, this is due to digging wells that are too deep and the location of excavation sites, as well as the conditions of the elements soil which also affects the chemical and physical elements found in the well water. Where the condition of the well water in Bintaran Village, Air Salek Sub-district, there is a color that is not too white, white (clear), and cloudy (yellow), because there are many in the lowlands, swamps, and left and right are rivers. In addition, climate factors, vegetation, geomorphology, and physiography also influence.

There are several wells that have salty in Bintaran Village, Air Salek Sub-district, and not all of them have the same taste and color of well water. The quality of dug well water can be affected by seepage of household waste water, chemical waste, laundry, seepage of nearby polluted river water, and others. (Marsono, 2009; Sasongko, et al., 2014)

Well water has different taste and color of water which can be influenced by the distance of the river to the well in Bintaran Village, Air Salek Sub-district. So this study wants to know the relationship of salt water wells to the distance of wells from the river.

\section{Research Methods}

This research was conducted in Bintaran Village, Air Salek Sub-district, Banyuasin District. Based on the research letter from Air Salek Sub-district, Banyuasin District, with Number: 070/10 / AS / 2019. This research was conducted to determine the relationship of the river to the salinity of well water in Bintaran Village, Air Salek Sub-district. The following is a sampling map at the research location: 

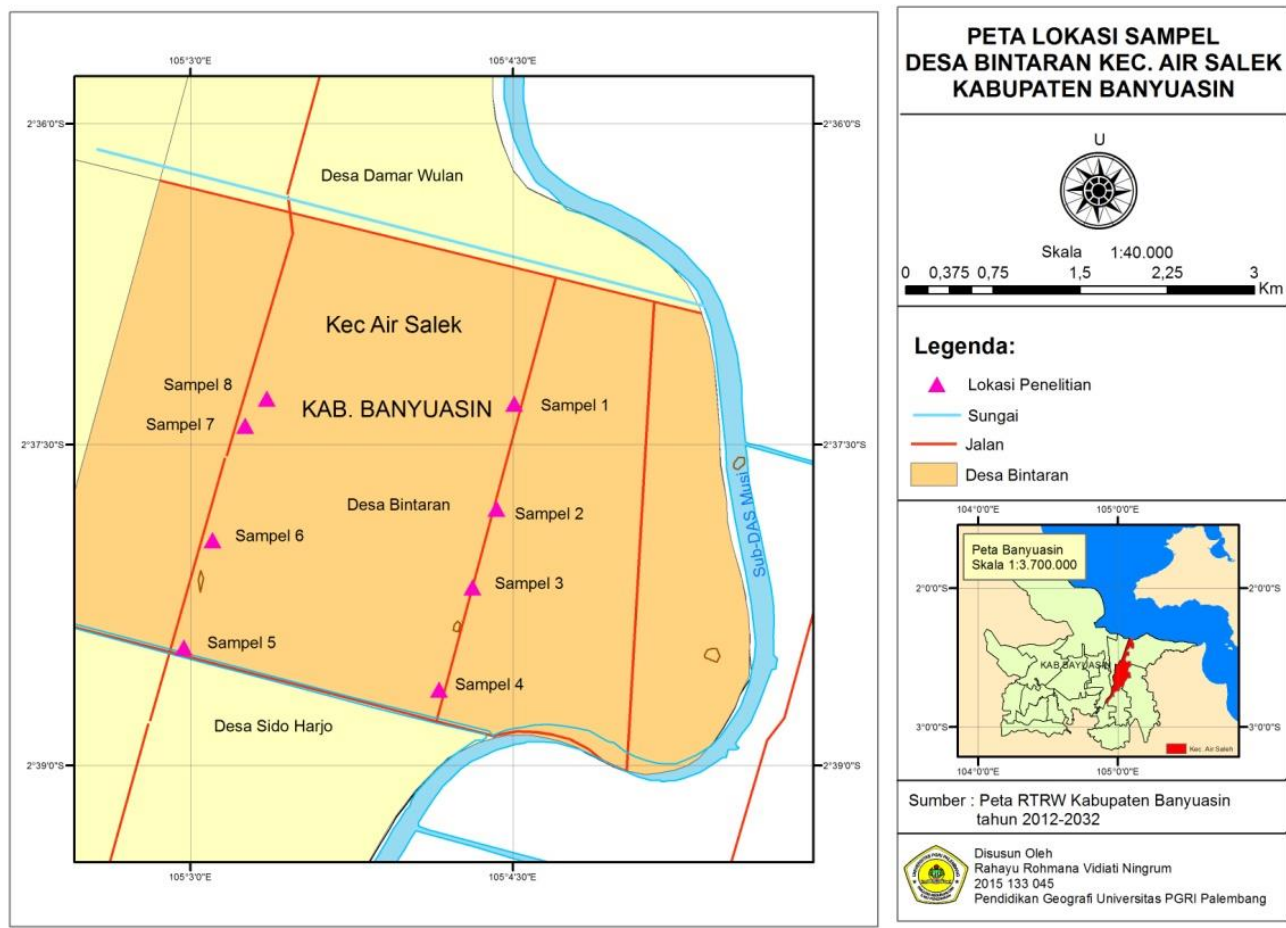

Figure 1. Map of the research location

Table 1. Research location

\begin{tabular}{|c|c|c|c|}
\hline \multirow{2}{*}{ sample } & \multicolumn{2}{|c|}{ Location } & Distance to Rivers / \\
& X (Longitude) & Y (Latitude) & Trenches (m) \\
\cline { 2 - 3 } & & & 1250 \\
\hline sample 1 & UTM 9710207 & $48 \mathrm{~m} 0508348$ & 2217 \\
\hline sample 2 & UTM 9709302 & $48 \mathrm{~m} 0508196$ & 1198 \\
\hline sample 3 & UTM 9707749 & $48 \mathrm{~m} 0507696$ & 257 \\
\hline sample 4 & UTM 9707745 & $48 \mathrm{~m} 0507698$ & 81 \\
\hline sample 5 & UTM 9708107 & $48 \mathrm{~m} 0505501$ & 1084 \\
\hline sample 6 & UTM 9709032 & $48 \mathrm{~m} 0505748$ & 2034 \\
\hline Sample 7 & UTM 9710017 & $48 \mathrm{~m} 0506030$ & 1761 \\
\hline sample 8 & UTM 9710252 & $48 \mathrm{~m} \mathrm{0506214}$ & \\
\hline
\end{tabular}

Source: Field Observation (Personal Documentation) 
This research uses quantitative methods, where the data collection method uses observation. The population of all wells is in the village with a number of 8 samples, each of which is taken 2 times in the morning and afternoon, for data analysis techniques using product moment correlation.

\section{Results}

\section{Water Hight}

Groundwater hight is interpreted or illustrated in the form of contour patterns of groundwater flow. Naturally, groundwater flow will cut perpendicular $\left(90^{\circ}\right)$ groundwater contours in a homogeneous and isotropic aquifer due to the influence of gravitational potential and have a flow direction from the high hydraulic head to lower groundwater level (Hendri, et, al., 2015).

Groundwater flows as in general, namely the nature of water flowing from high to a lower place, where in the village of Bintaran, Air Salek Sub-district the water level varies. Based on the results of terrestrial measurements the groundwater level can be obtained at the highest morning measurements of sea level which is $21.44 \mathrm{~m}$, and the lowest water level is $1.42 \mathrm{~m}$, and the average water level in the morning measurement is $11.61 \mathrm{~m}$. While the water level in the afternoon measurements in this study is $21.55 \mathrm{~m}$, and the lowest is $1.45 \mathrm{~m}$, and the average water level measurement in the study is $11.69 \mathrm{~m}$ from the surface. the sea.

Difference in water level in the morning and afternoon sample measurements, that is 1 morning and afternoon sample has a difference, which is $10 \mathrm{~cm}, 2$ morning and afternoon samples have a difference, $4 \mathrm{~cm}, 3$ morning and afternoon samples have a difference, $11 \mathrm{~cm}$, 4 morning samples and afternoon has a difference, namely $3 \mathrm{~cm}$ sample 5 in the morning and afternoon has a difference, which is $9 \mathrm{~cm}$, sample 6 in the morning and afternoon has a difference, which is $5 \mathrm{~cm}$, sample 7 in the morning and afternoon has a difference, $9 \mathrm{~cm}$ and sample 8 in the morning and afternoon has difference, which is $10 \mathrm{~cm}$. To be clearer in the pattern of groundwater flow can be seen in the map image, as follows: 

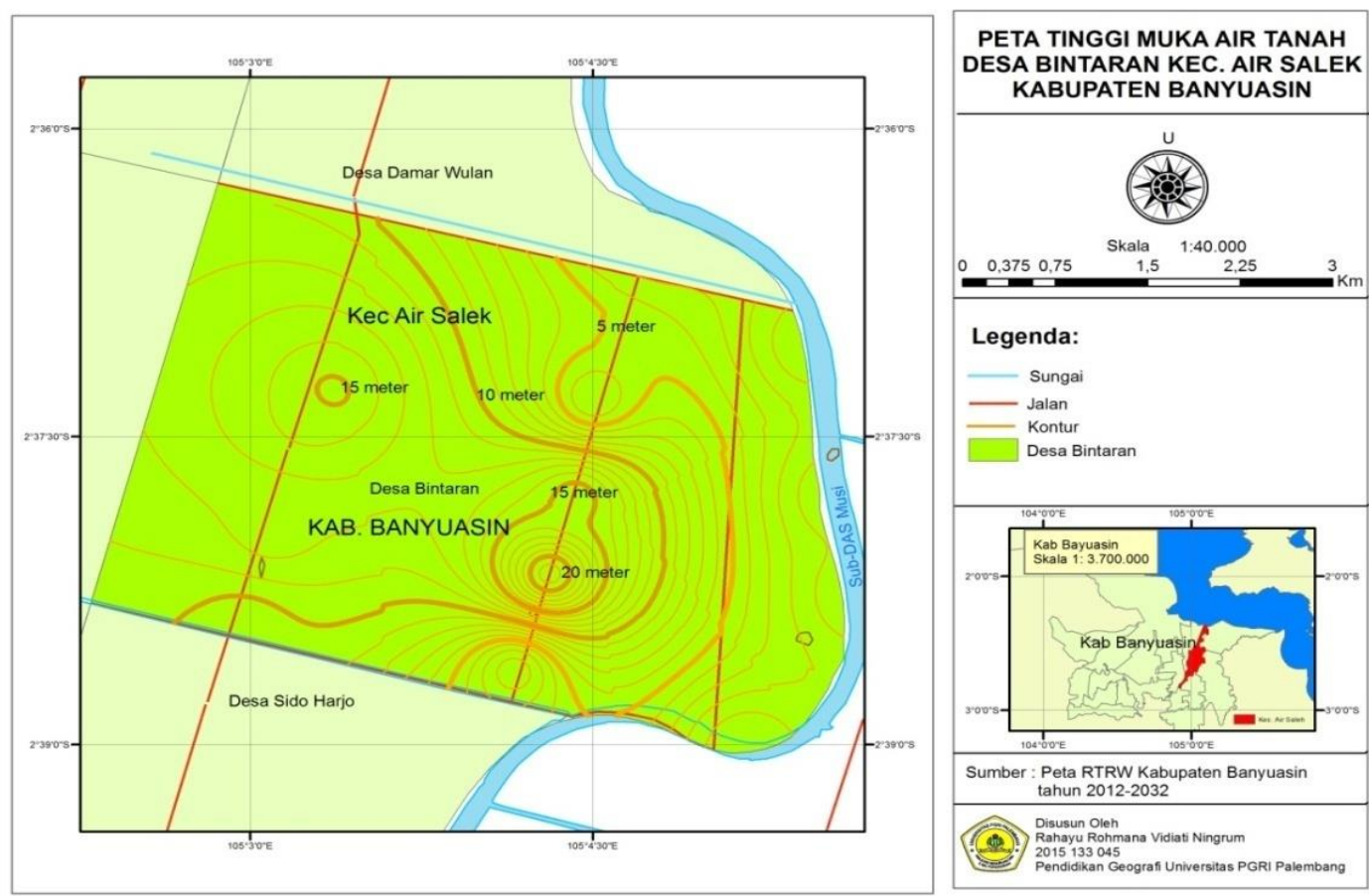

Figure 2. Map of Groundwater Height in Bintaran Village, Air Salek Sub-District

Based on the water level graph can be described as follows:

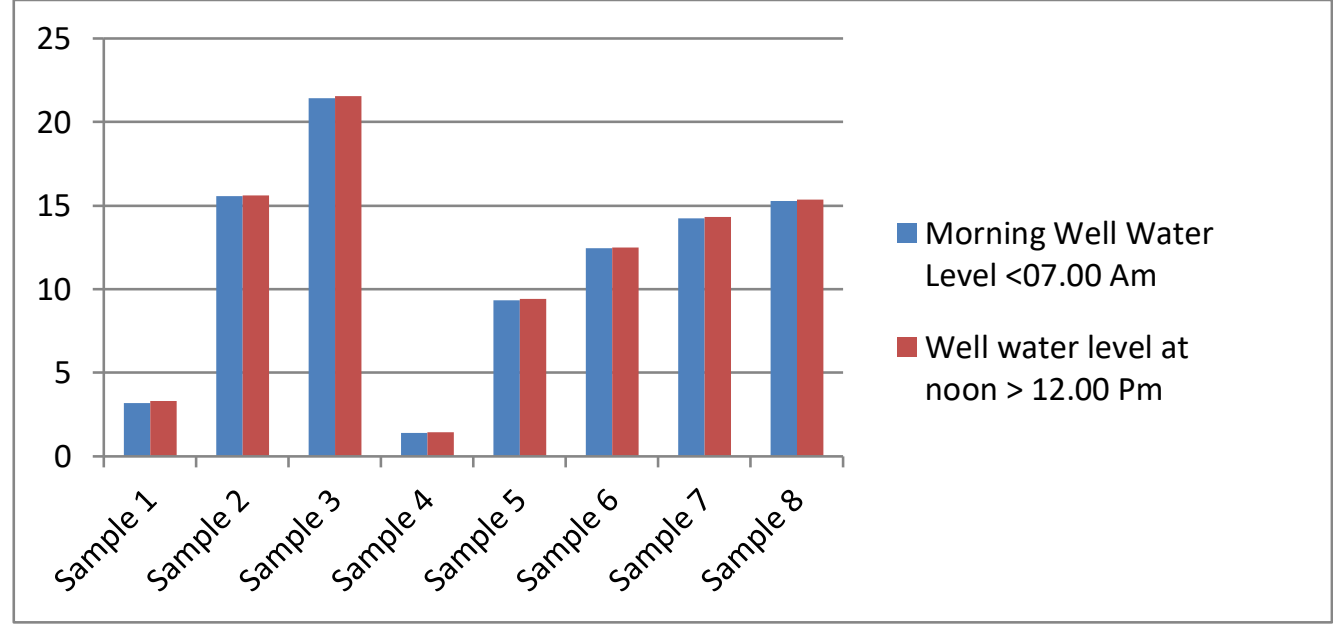

Graph 1. Results of Well Surface Water

So the difference between the highest water level, which is $10 \mathrm{~cm}$ and the lowest difference is $3 \mathrm{~cm}$, and the average has a water level with a difference in height that is reaching $8 \mathrm{~cm}$. 


\section{Level of Salt (Salinity)}

Salt content is a salt content dissolved in ground water, which is influenced by geographical location, pollution found in the environment, and water irrigation in the village. The level of salt or salinity in Bintaran Village, Air Salek Sub-district, the salt content is high compared to generally groundwater. In general, ground water is water that has no taste, has a smell, does not have color.

Salt content (salinity) from the results of the Palembang BBLK laboratory test in Bintaran Village, Air Salek Sub-district, which is where the highest salinity is found in samples 7 in the morning and afternoon, with salinity $(2.93 \%$ ) and afternoon $2.95 \%$. Salinity, the lowest is in the sample 4 morning and afternoon, that is with the results of salinity morning $0.24 \%$, and afternoon $0.23 \%$. The average salinity in the morning well water sample is $1.23 \%$, and the average salinity well water during the afternoon take is 1.19 \%. To be more clear, it can be described graphically from the results of laboratory tests for Palembang BBLK (Health Laboratory Center), as follows:

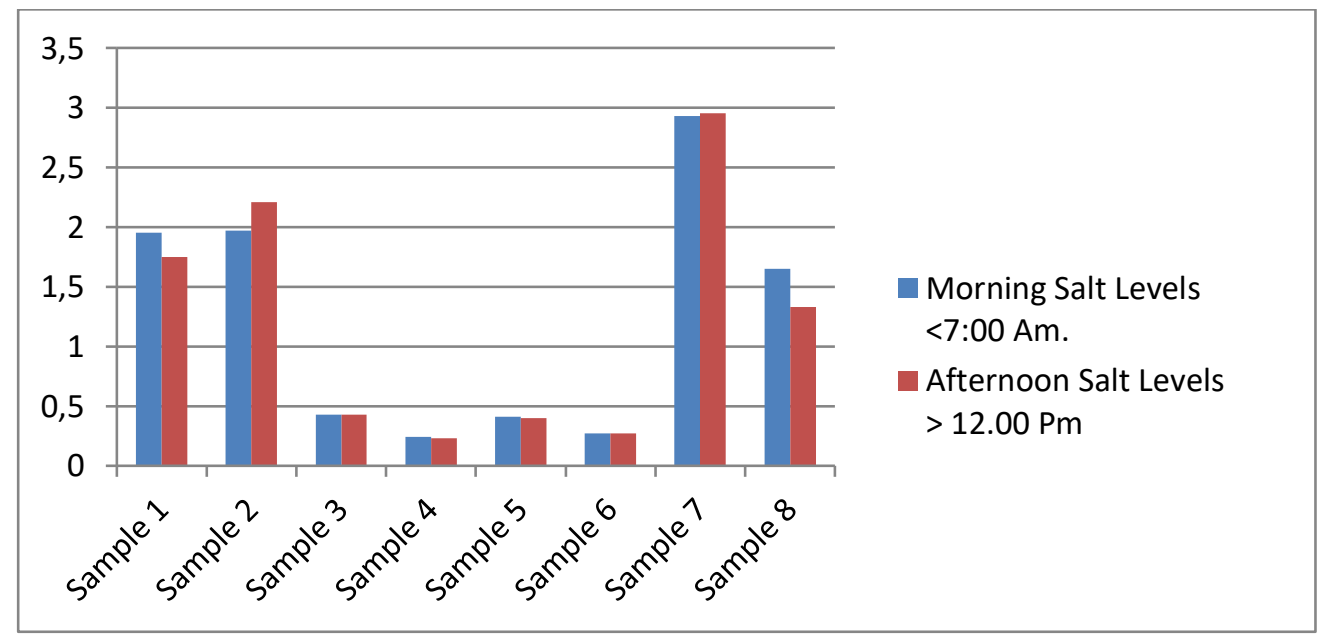

Graph 2. Results of the level of salt (salinity) of well water 
So the morning and afternoon salt levels based on the results of tables and graphs have an average difference of $4 \%$.

\section{Relationship between Salt Levels to the Distance of Wells from the River}

The river is a supplier of fresh water. Well water in Bintaran Village, Air Salek Subdistrict is ecologically located on the alauvial plain, which is in the tidal swamp area, so that the well water generally has a higher salt content than well water which is not located in tidal swamp areas. Where the well water is generally good, well water that has a tasteless and tasteless taste, and does not smell, however, well water in tidal areas tends to be salty fluctuating, ie where in the dry season the salt content is higher which has a taste salty ones, but during the rainy season the salt content is low. This can be indicated by the presence of fresh water into the well water, so that the well water mixes with the fresh water so that it affects the salt content in it, one of which is the river.

Based on the hypothesis, if the salt content is less than $0.05 \%$ then there is a relationship between the salinity of the distance of the well from the river, so Ho is rejected and $\mathrm{Ha}$ is accepted ie there is a relationship between the salinity of the well distance from the river. It is evident from the relationship between the salinity found in the well and the distance of the well from the river has significant in the morning sample where the value is 0.794 . Where t count 16.23 is greater $t$ table 2.447 , so Ho is rejected. This means that there is a positive relationship and the correlation coefficient between salinity in the morning to the well distance from the river is 0.927 .

The salt content in the daytime also has a significant relationship between the salinity of the distance of the well from the river, as evidenced by the value of $t$ count 6.09 greater $t$ table 2.447, so Ho is rejected. This means that there is a positive relationship and the correlation coefficient value between the day salt content of the well distance from the river is 0.9277882 .

\section{Discussion}

Based on the results of the above data analysis, variable $\mathrm{X}$ (distance of the river with wells) and variable Y (salinity), a correlation index is obtained which indicates that there is a significant relationship between the river to the salinity of well water. Based on the results of the correlation analysis of salt levels for the morning sample which is 0.794 and in the afternoon sample is 0.807 , it is found that the coefficient of determination is $r^{2}=0,794^{2}=$ 
0,63 . This means that the variance that occurs at morning salt levels is $63 \%$ and $37 \%$ which affects the presence of such salts as one of the rainfall factors, whereas for the day salt content the coefficient of determination is $r^{2}=0,807^{2}=0,65$. This shows that the variance that occurs at $65 \%$ daytime salt content and $35 \%$ that affects it, such as one of them is evaporation so that it can affect the salt content. The morning and afternoon salt levels of the well distance from the river based on coefficient of efficiency the level of relationship has a strong relationship, so Ha is accepted because $\mathrm{t}$ count is greater than $\mathrm{t}$ table so Ho is rejected, so there is a positive relationship between salinity and well distance from the river .

Thus it can be seen that between the salinity of well water and the river there is a significant relationship, namely getting closer to the river, decreasing the salt content, and what if the river distance from the well is high, because the further the river lies well the influence of rivers with wells has not affected the well water much as according to the research journal (Zhang, 2010), explaining that "the length of salt intrusion depends on river discharge".

Although it is significant but there is an anomaly in sample 5 which is located close to the river but the salt content is high. In addition to the salt content that can affect the contour of ground water is also very related, where the contour of ground water is lower if the location of the well water is close to the river, so the salt content is low, because many receive fresh water, as in research according to (Pudja, 2009) explains that "saltwater instructions can occur anywhere, even in the interior (inland)".

Thus the researchers concluded that the closer the distance of the river to the well, the lower the salinity contained in the well, and if the distance from the river to the well farther then the salinity contained in the well water is higher. However, it can be recognized that the salinity of well water is not affected solely by the distance of the well with the river, but there are several other factors that affect the salinity of well water as according to research (Patty, 2013) explaining that "salinity is affected by several factors including the pattern of water circulation, evaporation, rainfall (precipitation) and the presence of river flow (run off)".

\section{Conclusions and Recommendation}

\section{Conclusion}

This research can be concluded, that the closer the location of the well to the river, the salt content in the well water is low, while the further the location of the well with the river, 
the higher the salt content in the well water. It is evident from the results of the product moment correlation statistical analysis that there is a significant relationship between the salinity of well water on the distance of the well from the river, from the magnitude of correlation coefficient on the morning 0.794 and afternoon 0.807 , the coefficient of correlation between relations has a strong relationship.

\section{Recommendation}

Based on the conclusions above, this research was carried out in Bintaran Village, Air Salek Subdistrict, concerning the relationship between the river and the salinity of well water, so the researcher gave several suggestions, as follows:

1) For the people of Bintaran Village, Air Salek Sub-district, to pay more attention to making wells with river distances, so that later the well water will not be too high in salt.

2) For relevant agencies, to provide guidance on the construction of wells based on distance from the river.

3) For the next researcher, this research can be a reference, about the need for further research on the findings of the research in solving practical problems, especially about the distance of wells from rivers to salt levels in Bintaran Village, Air Salek Sub-district.

\section{References}

Hendri, A., Sutikno, S., and Saldanela. (2015). Groundwater Flow Based on Geographic Information System (Sig) in the Handsome Area of Pekanbaru City (In Indonesian). FTEKNIK Jom, 2 (1). https://studylibid.com/doc/665261/ mapping-ground-water-flow pattern.

Kumar, A., Talwar, A., Bisht, B. S., Singh, A. K., \& Joshi, V. D. (2017). Physical, Chemical and Bacteriological Studies of Water from the Uttarakhand River. Journal of Human Ecology, 32 (3), 169-173. https://doi.org/10.1080/ 09709274.2010.11906336

Marsono. 2009. Factors Associated with Bacteriological Quality of Well Water Digging in Settlements, Study in Karanganom Village, North Klaten District, Klaten (In Indonesian). Thesis. Masters Program in Environmental Sciences, Diponegoro University. 
Sasongko, E. B., Widyastuti, E., \& Priyono, R. E. (2014). Study of Water Quality and Use of Dug by the Community Around the Kaliyasa River, Cilacap Regency (In Indonesian). Journal of Environmental Sciences, 12 (2), 72. https://doi.org/10. 14710 / jil.12.2.7282.

Schlesinger WH 1991. Biogeochemistry: An Analysis of Global Change. New York: Academic Press Inc.

Patty, S. I. (2013). Journal of Scientific Temperature, Salinity and Dissolved Oxygen in Kema Waters, North Sulawesi 1 Temperature Distribution, Salinity and Dissolved Oxygen in Kema Waters, North Sulawesi. Platax Scientific Journal. Platax Scientific, 1 (3), 148-157.

Pudja, P. and Octonovrilna, L. (2009). Comparative Analysis of Gravity Anomalies with Distribution of Saltwater Intrusions (In Indonesian). Jakarta. Journal of Meteorology and Geophysics, 10 (1), 39-57. http://puslitbang. bmkg.go.id.

Zhang, Z., Cui, B., Zhao, H., Fan, X., \& Zhang, H. (2010). Relationship between DebitSalinity at Modaomen Waterway, Pearl River Estuary. Procedia Environmental Sciences, 2 (5), 1235-1245. https://doi.org/ 10.1016/j.proenv. 2010.10.134

Zhao, X., Othmanli, H., Schiller, T., Zhao, C., Sheng, Y., Zia, S., Stahr, K. (2015). Efficiency of Water Use in Soil Saline Under Cotton Cultivation in the Tarim Watershed. Water (Switzerland), 7 (6), 3103-3122. https://doi.org/10. 3390 / w7063103 